\title{
$\underbrace{}_{\mathrm{J} \text { B E }} \mid \begin{array}{ll}\text { JOURNAL OF } & \text { E-ISSN 2656-3436/ P-ISSN 2615-3947 } \\ \text { BIOLOGY } & \text { IAIN KUDUS } \\ \text { EDUTION } & \text { Tersedia online: http://journal.iainkudus.ac.id/index.php/jbe }\end{array}$
}

\section{Penggunaan Simulasi Praktikum Melalui Self Assessment Pada Kinerja (Performance) Pengamatan Sel Darah}

\author{
Didi Nur Jamaludin ${ }^{1)}$, Sulasfiana Alfi Raida ${ }^{2)}$ Wasis Wuyung Wisnu Brata ${ }^{3)}$ \\ Indah Listianingsing ${ }^{4}$ \\ Program Studi Tadris Biologi Institut Agama Islam Negeri Kudus ${ }^{1,4}$ \\ Program Studi Tadris IPA Institut Agama Islam Negeri Kudus ${ }^{2}$ \\ Program Studi Pendidikan Biologi Universitas Negeri Medan ${ }^{3}$ \\ didinj@iainkudus.ac.id ${ }^{1)}$,sulasfiana90@gmail.com²) wasisbrata@unimed.ac.id ${ }^{3)}$ indah11listianingsinh @gmail.com $\left.{ }^{4}\right)$
}

\begin{abstract}
ABSTRAK
Penilaian praktikum seringkali kurang memberikan penguatan umpan balik kepada mahasiswa karena penilaian praktikum kadang diletakan pada waktu penghujung akhir semester. Penelitian ini menggunakan pendekatan kuantitatif jenis kuasi eksperimen tipe the matching only posttest only control group design. Kegiatan simulasi praktikum dengan self assessment dilakukan dengan memberikan kriteria-kriteria kemampuan dasar yang harus dikuasai dalam melakukan pengamatan toleransi osmotik sel darah merah (eritrosit) dan preparat sel darah putih (leukosit). Hasil penelitian menggunakan simulasi praktikum dengan self assessment menunjukkan keterampilan kinerja (performance) mahasiswa dalam pengamatan sel darah dengan hasil signifikan lebih baik dibandingkan penggunaan simulasi praktikum biasa. Kegagalan dalam mengamati sel darah, seringkali karena menggunakan perbesaran, mikrometer dan makrometer mikroskop yang tidak sesuai sehingga menghabiskan alokasi waktu yang tersedia. Simulasi praktikum dengan self assessment memberikan kesempatan kepada setiap mahasiswa untuk menilai kemampuan diri dalam menggunakan mikroskop, selain itu juga perlu memiliki strategi khusus agar dapat melakukan pengamaatan objek secara benar, cepat dan efektif. Simulasi tersebut mendorong untuk memunculkan sikap tanggung jawab agar dapat mencapai keterampilan kinerja.
\end{abstract}

Kata Kunci: simulasi praktikum; self assessment; performance; sel darah 


\begin{abstract}
The practical assessment often lacks reinforcement of feedback to students, because it is sometimes placed at the end of semester. This research method uses quantitative research the type quasi experimental and matching only posttest only control group design. The practical simulation activities with self-assessment are carried out by providing basic capability criteria that must be mastered in observing osmotic tolerance of erythrocytes cells and preparations of leukocytes cells. The results of the study using practical simulations with self assessment show the performance skills of students in observing blood cells with significantly better results than using ordinary practical simulations. Failure to observe blood cells, often due to the use of improper magnifications, micrometers and microscope microscopes so that they use up the available time. Practical simulations with selfassessment provide an opportunity for every student to assess their ability to use a microscope, while also needing to have a special strategy in order to be able to object fastly, correctly and effectively. The simulation encourages responsibility for attaining performance skills.
\end{abstract}

Keywords: practical simulation; self assessment; performance; blood cell

\title{
PENDAHULUAN
}

Pembelajaran mata kuliah fisiologi hewan diarahkan pada pembelajaran yang sesuai dengan hakikat sains yakni pertama sains sebagai produk berupa informasi yang berkaitan dengan konsep dasar, prinsip dan hukum sains, kedua sains sebagai proses harus mencerminkan pembelajaran yang mengembangkan metode ilmiah dan pendekatan saintifik dan sains sebagai sikap ilmiah harus mendorong mahasiswa untuk memiliki sikap ilmiah. National Science Teachers Association (2009; 61-65) menjelaskan IPA berkembang dari interpretasi data yang dikumpulkan melalui pengamatan, penyelidikan dan percobaan sehingga IPA memiliki tiga dimensi yakni produk ilmiah (scientific product), proses ilmiah (scientific process), sikap ilmiah (scientific attitude), dan aplikasi dalam kehidupan seharihari.

Kegiatan praktikum diharapkan dapat mendorong pembentukan Keterampilan Proses Sains dan sikap ilmiah. Menurut Ali, Ruslan, dan Jumadi (2014) untuk mengevaluasi kinerja (performance) mahasiswa dalam melakukan praktikum di laboratorium diperlukan format penilaian yang mencakup aspek-aspek keterampilan proses sains sesuai tuntutan kurikulum seperti mempersiapkan alat, merangkai alat, mengamati, menganalisis data, menyusun laporan, dan sebagainya yang memenuhi kriteria valid, realibel, obyektif dan praktis. Berdasarkan hasil penelitian itu lebih difokuskan pada pengembangan format penilaian keterampilan proses sains, penelitian tersebut belum dilakukan pengujian studi penelitian eksperimen. 
Berdasarkan hasil observasi dalam kegiatan praktikum pengamatan sel darah, bahwa aktivitas pembelajaran di laksanakan dalam bentuk kelompok. Keunggulan dari pembelajaran kelompok untuk mengembangkan sikap ilmiah salah satunya membangun kerjasama, namun disisi lain dalam kelompok ada beberapa mahasiswa yang tidak melakukan pengamatan secara baik. Oleh karena perlu penilaian keterampilan kinerja (performance) yang berpusat pada setiap individu.

Hal lain dalam penilaian praktikum seringkali kurang memberikan penguatan umpan balik kepada mahasiswa, karena penilaian praktikum sering kali diletakan pada waktu penghujung akhir semester. Padahal jika dicermati penilaian praktikum bukan sekedar dimaknai sebagai hasil penilaian (assessment of learning), akan tetapi ada umpan balik dan penguatan proses agar mahasiswa dapat memiliki penilaian diri untuk memenuhi standar dan kriteria yang telah ditentukan (assessment for learning). Hasil penelitian Sharma dkk (2016: 229) menunjukkan penilaian diri (self-assessment) dengan umpan balik (feedback) dapat meningkatkan pengetahuan (knowledge) peserta didik.

Upaya untuk memperkuat kinerja mahasiswa dalam kegiatan praktikum diperlukan sebuah simulasi dilengkapi penilaian diri (self assessment) sebelum pelaksanaan penilaian kinerja (performance assessment). Hal ini dilakukan agar mahasiswa memiliki percaya diri dan kesiapan untuk beradaptasi dengan berbagai alat dan bahan yang akan digunakan untuk penilaian kinerja dalam pengamatan sel darah dengan mikroskop. Oleh karena itu peneliti tertarik menggunakan penilaian diri (self assessment) untuk dikaji pengaruhnya terhadap keterampilan kinerja. Hal tersebut juga menjadi pembeda dari penelitian yang lain, karena seringkali mengkaji penilaian diri berkaitan dengan sikap dan prestasi belajar.

\section{METODE PENELITIAN}

Metode penelitian ini menggunakan pendekatan penelitian kuantitatif dengan jenis kuasi eksperimen tipe the matching only posttest only control group design (Fraenkel dan Wallen 2007: 271-281). Penelitian dilakukan pada mahasiswa yang mengikuti perkuliahan fisiologi hewan di program stdui pendidikan biologi IAIN Kudus. Sampel penelitian menggunakan teknik pengambilan sampel acak kelompok (cluster random sampling), masing-masing terdiri kelas eksperimen sebanyak 34 mahasiswa dan kelas kontrol sebanyak 36 mahasiswa. Penelitian menggunakan dua kelas, dengan perlakuan pertama kelas eksperimen menggunakan simulasi penilaian diri (self assessment) dan kelas kontrol hanya menggunakan simulasi praktikum tanpa self assessment.

Penggunaan simulasi praktikum melalui self assessment dengan memberikan kriteria penilaian dalam pengamatan sel darah merah dengan perlakuan toleransi osmotik sel darah merah (eritrosit) dan pengamatan preparat kering sel darah putih (leukosit). Kemudian dosen menilai keterampilan kinerja mahasiswa dalam menggunakan mikroskop, akurasi menentukan objek dan penguasaan konsep yang dimiliki dengan menggunakan lembar performance assessment. Rumusan hipotesis alternatif menyatakan terdapat perbedaan 
signifikan kemampuan kinerja (performance) antara kelas eksperimen yang menggunakan simulasi praktikum dengan self assessment dibandingkan dengan kelas kontrol yang menggunakan simulasi praktikum pada pengamatan sel darah.

\section{HASIL DAN PEMBAHASAN}

Upaya dosen untuk memperkuat pemahaman tentang sel darah pada materi sistem osmoregulasi dan sistem peredaran darah, tidak hanya disampaikan melalui kegiatan tatap muka secara teoritis melainkan perlu melakukan kegiatan praktikum (eksperimen) untuk melihat berbagai aktivitas sel darah merah (eritrosit) dalam berbagai konsentrasi larutan $\mathrm{NaCl}$ baik dalam keadaan isotonis, hipotonis, hipertonis dan pengamatan preparat sel darah putih (leukosit).

Desain pembelajaran dalam mata kuliah fisiologi hewan berupa kegiatan teori dan praktikum. Adapun untuk penelitian ini ditambahkan kegiatan simulasi praktikum dengan self assessment dan tanpa menggunakan self asessement. Kegiatan praktikum tersebut mendukung dalam pembelajaran materi sistem osmoregulasi dan sistem peredaran darah, sehingga kegiatan belajar berupa pembelajaran teori, pembelajaran praktikum, simulasi praktikum dan penilaian kinerja (performance assessment).

Mc Millan, J H. \& Hearn, J. (2008:22) menjelaskan bahwa penilaian diri dimaknai sebagai proses ketika peserta didik melakukan aktivitas, Pertama memonitor dan mengevaluasi pikiran (thinking) dan tingkah laku (behavior) mereka ketika belajar. Kedua Mengidentifikasi strategi untuk meningkatkan pemahaman dan keterampilan (skill) mereka. penilaian diri terjadi ketika peserta didik menilai pekerjaan mereka sendiri untuk meningkatkan kinerja melalui identifikasi perbedaan antara kinerja saat ini dan yang diinginkan. Aspek penilaian diri ini selaras dengan pendidikan yang berbasis standar, dengan memberikan tujuan dan kriteria jelas untuk dapat memfasilitasi penilaian diri peserta didik.

Spiller (2012) menjelaskan proses penilaian seringkali pendidik berperan utama dan memberikan batasan potensi pengembangan peserta didik. Maka tugas self assessment menggeser fokus dari sesuatu yang dipaksakan oleh orang lain ke arah kemitraan potensial (potential partnership). Menurut Andrade dan Du (2007) self assessment adalah proses

penilaian formatif selama dimana siswa merefleksikan dan mengevaluasi kualitas bekerja dan belajarnya, menilai mereka pada pencapaian tujuan atau kriteria yang dinyatakan secara eksplisit, mengidentifikasi kekuatan dan kelemahan dalam pekerjaannya dan upaya memperbaikinya.

Kegiatan simulasi praktikum dengan self assessment dilakukan dengan memberikan kriteria-kriteria kemampuan dasar yang harus dikuasai dalam melakukan pengamatan toleransi osmotik sel darah merah dan preparat sel darah putih. Dosen memberikan penjelasan kemampuan dasar ketika menggunakan mikroskop dengan mengarahkan lebih disiplin dalam menghidupkan dan mematikan lampu mikroskop, meletakan kaca preparat dan penutup secara tepat, memilih lensa objektif yang tepat, menggunakan makrometer dan 
mikrometer secara tepat, agar dapat melihat objek pengamatan secara tepat dan jelas. Mahasiswa diarahkan untuk mencoba melakukan pengamatan bagi setiap individu, yang sudah bisa atau yang belum mencoba saat praktikum sebelumnya.

Self assessment memiliki tiga komponen siklus meliputi monitoring diri (self monitoring), evaluasi diri (self evaluation), dan identifikasi dan implementasi pembelajaran sesuai kebutuhan. Secara prinsip peserta didik dapat mengidentifikasi strategi pembelajaran dan kinerjanya, memberikan umpan balik kepada diri sendiri berdasarkan standar dan kriteria yang dipahami dengan baik, dan menentukan langkah atau rencana lanjutan untuk meningkatkan kinerjanya (enhance their performance). (McMillan, J H. \& Hearn, J, 2008: 41). Jadi ketika simulasi praktikum dengan self assessment memberikan kesempatan kepada setiap mahasiswa untuk menilai kemampuan diri dalam menggunakan mikroskop, selain itu juga perlu memiliki strategi khusus agar dapat melakukan pengamaatan objek secara benar, cepat dan efektif.

Sementara itu di kelas kontrol juga diberikan kesempatan yang sama untuk melakukan simulasi praktikum setiap individu untuk mencoba. Keterampilan menggunakan mikroskop merupakan keterampilan dasar yang pernah diperkenalkan pada mata kuliah sebelumnya seperti Biologi Dasar, Teknik Laboratorium, Anatomi dan lain sebagainya. Penggunaan mikroskop juga menjadi keterampilan dasar untuk mengembangkan keterampilan proses sains dan sikap ilmiah seperti teliti, pantang menyerah dan objektif. Hasil simulasi praktikum seringkali dijumpai mahasiswa tidak disiplin dalam mematikan lampu mikroskop, hal inilah yang menjadi fokus perhatian dalam keterampilan kinerja.

Instrumen yang digunakan dalam menilai keterampilan kinerja (performance) pengamatan sel darah, dengan menggunakan ceklis seperti Tabel 1.1. Instrumen itu digunakan dengan pertimbangan mudah digunakan dan indikator pencapaian mudah diamati. Dosen memberikan alokasi waktu yang standar untuk penyelesaian dua kegiatan pengamatan toleransi osmotik sel darah merah dan pengamatan inti sel darah putih. Jika mahasiswa belum selesai akan tetapi waktu telah habis, maka hasil tersebut masuk dalam penilaian keterampilan kinerja. 
Tabel 1.1 Instrumen Performance Assessment untuk Pengamatan Toleransi Osmotik Sel Eritrosit dan Pengamatan Sel Leukosit

Petunjuk : a. Berilah tanda ceklis (V) pada pilihan ya atau tidak

b. Penilaian dari jumlah ceklis pada bagian pilihan ya dengan skala 0-100.

\begin{tabular}{|l|l|l|l|}
\hline \multicolumn{1}{|c|}{ Nama Indikator } & \multicolumn{1}{|c|}{ Kelas:................... } \\
\cline { 3 - 4 } No & \multicolumn{1}{|c|}{ Pilihan } \\
\hline 1 & Menghidupkan dan mematikan lampu mikroskop & & Ya \\
\hline 2 & Meletakkan preparat kaca objek dengan tepat & & \\
\hline 3 & Meletakkan preparat kaca penutup dengan tepat & & \\
\hline 4 & Memilih lensa objektif dengan tepat & & \\
\hline 5 & Menggunakan makrometer secara terampil & & \\
\hline 6 & Menggunakan mikrometer secara terampil & & \\
\hline 7 & Menemukan objek pengamatan I secara tepat & & \\
\hline 8 & Menemukan objek pengamatan II secara tepat & & \\
\hline 9 & Menjelaskan bagian objek pengamatan I secara tepat & & \\
\hline 10 & Menjelaskan bagian objek pengamatan II secara tepat & & \\
\hline \multicolumn{2}{|c|}{ Nilai Total } & & \\
\hline
\end{tabular}

Analisis data penelitian melalui uji prasyarat melalui uji normalitas dan homogenitas pada penilaian keterampilan kinerja (performance) mahasiswa dalam melakukan pengamatan sel darah menunjukkan data normal dan homogen. Analisis data pengujian hipotesis menggunakan analisis SPSS dengan independent semples t-test seperti pada Tabel 1.2 .

Tabel 1.2 Uji perbedaan rata-rata keterampilan kinerja (performance)

\begin{tabular}{|c|l|l|c|c|c|}
\hline No & Kelas & Desain Perlakuan & $\begin{array}{c}\text { Rata-Rata } \\
\text { Keterampilan } \\
\text { Kinerja }\end{array}$ & $\begin{array}{c}\text { Standar } \\
\text { Deviasi }\end{array}$ & $\begin{array}{c}\text { Taraf } \\
\text { Signifikansi }\end{array}$ \\
\cline { 1 - 4 } 1 & Eksperimen & $\begin{array}{l}\text { Simulasi praktikum } \\
\text { dengan self } \\
\text { assessment }\end{array}$ & 80,59 & 8,85 & \multirow{2}{*}{} \\
\cline { 1 - 3 } 2 & Kontrol & Simulasi praktikum & 73,89 & 11,28 & \\
\hline
\end{tabular}

Berdasarkan data tersebut menunjukkan nilai taraf signifikansinya dengan nilai Asymp. Sig $(2$-tailed $)<0,05(0,008<0,05)$ maka $\mathrm{H}_{\mathrm{a}}$ diterima. Hal tersebut menunjukkan bahwa penggunaan simulasi praktikum dengan self assessment menunjukkan kemampuan 
kinerja (performance) mahasiswa dalam pengamatan sel darah dengan hasil yang lebih baik dibandingkan penggunaan simulasi praktikum biasa tanpa self assessment.

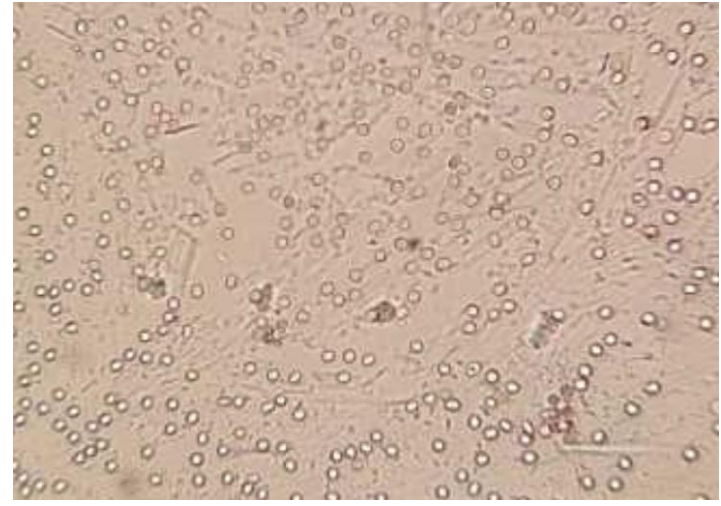

Gambar 1.1.Pengamatan toleransi osmotik sel darah merah (perbesaran hasil edit dari foto)

Kegiatan praktikum praktikum toleransi osmotik sel darah merah, memiliki perlakuan khusus berupa pemberian larutan $\mathrm{NaCl}$ dengan konsentrasi yang beragam dari konsentrasi $0,5 \%$ sebagai larutan hipotonis, konsentrasi $0,9 \%$ sebagai larutan isotonis dan hingga $3 \%$ sebagai larutan hipertonis. Ketika praktikum pengamatan sel darah merah, sebagian mahasiswa mengalami kesulitan dalam mengidentifikasi fenomena sel darah ada yang mengalami mengkerut atau krenasi dan ada juga sel darah merah yang menggelembung seperti Gambar 1.1. Hal ini dikarenakan belum terbiasa melihat perubahan objek mikroskopis, selain itu juga belum bisa mengaitkah kaidah variasi konsentrasi larutan $\mathrm{NaCl}$ terhadap bentuk sel darah merah.

Adapun untuk pengamatan sel darah putih (leuksoit) menggunakan preparat yang sudah siap pakai dengan pewarnaan giemsa, agar waktu yang digunakan lebih efektif. Hasil pengamatan yang dilakukan mahasiswa beberapa terlihat seperti Gambar 1.2a dan 1.2b, hal ini dikarenakan perbesaran yang kurang tepat ataupun dari proses pewarnaan. Sebagian mahasiswa belum dapat menjawab alasan sel yang terwarnai dan perbedaan bentuk inti yang beragam. 




(a)

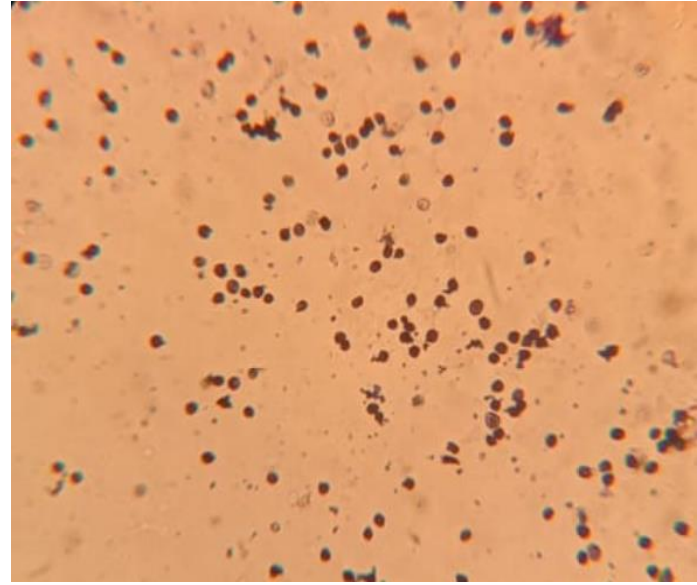

(b)

Gambar 1.2. Hasil pengamatan mahasiswa pada sel darah putih (leukosit) kadang menunjukkan seperti gambar a lebih jelas bentuk inti sel darah putih, namun paling banyak menemukan posisi seperti gambar b tidak jelas bentuk inti selnya. (perbesaran hasil edit dari foto).

Hasil performance assessment di kelas kontrol ada 4 mahasiswa yang belum mampu menemukan objek pengamatan sel darah merah dan sel darah putih. Kesulitan mereka yang belum bisa mengamati diantaranya penggunaan makrometer dan mikrometer yang belum terampil, sementara di kelas eksperimen ada 1 mahasiswa yang belum bisa mengamati secara baik, sementara mahasiswa yang lain memiliki variasi hasil pencapaian keterampilan kinerja.

Kegagalan dalam mengamati sel darah, seringkali karena mengunakan perbesaran, mikrometer dan makrometer yang tidak sesuai sehingga menghabiskan alokasi waktu yang tersedia. Oleh karena itu pengamatan menggunakan mikroskop agar lebih efektif itu memiliki strategi diantaranya menyadari bahwa perbesaran sel darah merah memiliki akurasi yang lebih tepat jika diamati dengan perbesaran 40X. Menurut Rolheiser \& Ross (2001) peserta didik yang diajari keterampilan evaluasi diri (self evaluation skills) cenderung memiliki ketahanan terhadap tugas-tugas sulit, menjadi lebih percaya diri terhadap kemampuannya, dan memiliki tanggung jawab yang lebih besar terhadap pekerjaannya.

Menurut Sharma dkk (2016: 229) menjelaskan bahwa self assessment dapat meningkatkan minat dan tingkat motivasi peserta didik untuk mengarah pada kinerja akademik yang lebih baik dan peningkatan belajar. Hal Ini juga dapat membantu dalam pengembangan keterampilan kritis peserta didik untuk menilai dan menganalisis pekerjaan yang dilakukan mereka sendiri serta hal paling utama menjadi komponen pembelajaran mandiri sepanjang hayat.

Pengetahuan self assessment dan keakuratan keterampilan kinerja (performance) sangat penting untuk praktik dunia medis dan menjadi petunjuk diri agar dapat belajar sepanjang hayat, karena sekarang setiap individu sendiri memiliki tanggung jawab atas 
keberlanjutan mereka sendiri dan pengembangan profesional (Antonelli, 1997:72). Berdasarkan hal tersebut efek dari self assessment mendorong untuk memunculkan sikap tanggungjawab agar bisa melakukan tugas/ keterampilan dasar yang harus dipenuhi.

Tingkat kesulitan yang menjadi tantangan dalam pengamatan toleransi osomotik sel darah merah saat kondisi normal, krenasi atau hemolisis karena ukurannya kecil, sehingga perubahan osmotik sel beberapa kasus tidak dapat dibedakan secara jelas. Sementara itu untuk pengamatan sel leukosit yang terwarnai oleh larutan giemsa, kadang mahasiswa kurang menyadari bahawa sel yang terwarnai memiliki bentuk dan nama yang berbeda seperti monosit dan neutrofil. Oleh karena itu dari hasil pengembangan penilaian diri (self assessment) dan penilaian kinerja (performance assessment) diharapkan dapat meningkatkan kinerja praktikum mahasiswa dengan penuh tanggung jawab dan dapat membangun pengetahuan secara kontekstual.

\section{SIMPULAN}

Kegiatan simulasi praktikum dengan self assessment dilakukan dengan memberikan kriteria-kriteria kemampuan dasar yang harus dikuasai dalam melakukan pengamatan toleransi osmotik sel darah merah dan preparat sel darah putih. Hasil penelitian penggunaan simulasi praktikum dengan self assessment menunjukkan keterampilan kinerja (performance) mahasiswa dalam pengamatan sel darah dengan hasil yang lebih baik dibandingkan penggunaan simulasi praktikum biasa. Kegagalan dalam mengamati sel darah, seringkali karena mengunakan perbesaran, mikrometer dan makrometer yang tidak sesuai sehingga menghabiskan alokasi waktu yang tersedia. Simulasi praktikum dengan self assessment memberikan kesempatan kepada setiap mahasiswa untuk menilai kemampuan diri dalam menggunakan mikroskop, selain itu juga perlu memiliki strategi khusus agar dapat melakukan pengamaatan objek secara benar, cepat dan efektif. Simulasi tersebut mendorong untuk memunculkan sikap tanggungjawab agar dapat memenuhi keterampilan kinerja dasar, yang harus dipenuhi. 


\section{DAFTAR PUSTAKA}

Ali, A. Ruslan, dan Jumadi,O. (2014). Pengembangan Perangkat Asesmen Praktikum Anatomi Fisiologi Manusia Berbasis Keterampilan Proses Sains Mahasiswa Jurusan Pendidikan Biologi UIN Alauddin Makassar. Vol 1 No 1 2014. Biotek. http://journal.uin-alauddin.ac.id/index.php/biotek

Andrade H, Du Y. (2007) Student responses to criteria- referenced self- assessment. Assessment \& Evaluation in Higher Education. Vol. 32, No. 2, April 2007. Diunduh https://scholarsarchive.library.albany.edu

Antonelli MA. (1997) Accuracy of Second- Year Medical Students' Self- Assessment Of Clinical Skills. Academic medicine : journal of the Association of American Medical Colleges

Fraenkel, J. R \& Wallen, N. E. 2007. How To Design and Evaluate Research in Education. Edisi 6. New York: The McGraw Hill Companies.

Mc Millan, J H. \& Hearn, J. (2008). Student Self-Assessment: The Key to Stronger Student Motivation and Higher Achievement. Educational Horizons, Vol 87 No1. Diunduh dari https://files.eric.ed.gov

National Science Teachers Association. (2009). The biology teacher's handbook (4th ed.). Virginia: National Science Teachers Association.

Rolheiser, C \& John A. (2001) "Student self-evaluation: What research says and what practice shows." Plain talk about kids

Sharma, dkk. (2016). Impact of self- assessment by students on their learning. International Journal of Applied and Basic Medical Research. Vol 6, Issue 3 2016. diunduh dari http://www.ijabmr.org

Spiller D. (2012). Assessment matters: Self-assessment and peer assessment, teaching development. Hamilton, New Zealand: The University of Waikato. 